\title{
Gestational age at birth and mode of delivery - analysis of 1280 cases of diabetic pregnancies and review of the literature
}

\author{
Wiek urodzeniowy noworodka i sposób zakończenia ciąży - analiza 1280 ciąż powikłanych \\ cukrzycą i przegląd piśmiennictwa
}

\author{
Aleksandra Rajewska ${ }^{1}, 2$, Zbigniew Celewicz², Andrzej Torbé1凶 \\ 1 Pomorski Uniwersytet Medyczny w Szczecinie, Klinika Perinatologii, Położnictwa i Ginekologii, ul. Siedlecka 2, $72-010$ Police \\ 2 Pomorski Uniwersytet Medyczny w Szczecinie, Klinika Położnictwa i Ginekologii, al. Powstańców Wlkp. 72 , 70-111 Szczecin \\ $\triangle$ torbea@wp.pl
}

\begin{abstract}
Introduction: The aim of the study to analyze the gestational age at delivery, delivery mode, and indications for caesarean section in 1280 women suffering from diabetes mellitus.

Materials and methods: The gestational diabetes (GD) group was divided into classes: G1 $(n=620)$ of women who needed diet only, and G2 ( $\mathrm{n}=524)$, who needed insulin administration. The pregestational diabetes (PGD) group was categorized in subgroups: of classes $B, C$ and $D-B C D(n=103)$ and of classes $R, F$ and $\mathrm{RF}(\mathrm{VC}$ - vascular complications) $(\mathrm{n}=33)$.

Results: In the GD-group $4.3 \%$ of deliveries occurred in $<34^{\text {th }}$ week of gestation, while in the PGD-group the percentage of such births was $10.29(\mathrm{p}=0.0045)$. The lowest percentage of deliveries $<34^{\text {th }}$ week was observed in G2, and the highest in the VC-subgroup. The occurrence of delivery $<37^{\text {th }}$ week in GD was lower than in the PGD-group $(p=0.002)$. It was rarest in G2 and most frequent in the VC-subgroup. The percentage of
\end{abstract}

caesarean section was lower in GD than in the PGD-group (47.94 vs. 74.26; $\mathrm{p}<0.001$ ). In the VC-subgroup it was near 100, while the lowest occurrence was noticed in the G1-subgroup. In both groups, caesarean delivery was performed more often because of foetal indications. Foetal indications prevailed in subgroups G1, G2 and BCD, while in the VC-subgroup most indications were of maternal condition.

Conclusions: Diabetes accompanying pregnancy increases the risk of preterm birth, especially in cases of pre-pregnancy diabetes complicated by vascular disease. Caesarean delivery is more often necessary in women with pre-pregnancy diabetes than in those with gestational diabetes mellitus. The most typical caesarean section among the diabetic women is that performed because of maternal indications in pre-pregnancy diabetes complicated by vascular disease.

Keywords: caesarean section; diabetes mellitus; pregnancy; preterm birth.

\begin{abstract}
ABSTRAKT
Wstęp: Celem pracy była analiza wieku urodzeniowego noworodków, sposobu rozwiązania i wskazań do cięcia cesarskiego w 1280 przypadkach ciąż powikłanych cukrzycą.

Materiały i metody: Ciężarne z cukrzycą ciążową (grupa GD) podzielono na podgrupę kobiet z cukrzycą klasy G1 $(\mathrm{n}=620)$, u których normalizację glikemii osiągnięto wyłącznie dzięki leczeniu dietetycznemu, oraz podgrupę kobiet z cukrzycą klasy G2 ( $\mathrm{n}=524)$, u których poza leczeniem dietetycznym stosowano również insulinoterapię. Ciężarne z cukrzycą rozpoznaną przed ciążą (grupa PGD) podzielono na podgrupę kobiet z cukrzycą klasy B, C i D (BCD; $\mathrm{n}=103)$ i na podgrupę kobiet z powikłaniami naczyniowymi VC (vascular complications), z cukrzycą klasy R, F i RF ( $\mathrm{n}=33)$.

Wyniki: W grupie GD 4,3\% porodów odbyło się przed ukończeniem 34. tygodnia ciąży, a w grupie PGD - 10,29\% ( $p=0,0045)$. Najniższy odsetek porodów <34. tygodnia ciąży zanotowano w podgrupie G2, a najwyższy w podgrupie VC. Również odsetek porodów przed ukończeniem 37. tygodnia ciąży był niższy
\end{abstract}

w grupie GD niż w grupie PGD $(p=0,002)$ i najniższy w podgrupie G2, a najwyższy w podgrupie VC. Odsetek rozwiązań cięciem cesarskim był niższy w grupie GD niż w grupie PGD (47,94 vs 74,26; $\mathrm{p}<0,001$ ). W podgrupie VC był on zbliżony do 100, z kolei najmniej cięć cesarskich miało miejsce w podgrupie G1. W obu grupach cięcia cesarskie wykonywane były najczęściej ze wskazań płodowych. Wskazania płodowe dominowały w podgrupach G1, G2 i BCD, podczas gdy w podgrupie VC cięcie cesarskie wykonywano najczęściej ze względu na matkę.

Wnioski: Cukrzyca w przebiegu ciąży zwiększa ryzyko porodu przedwczesnego. Dotyczy to w szczególności przypadków cukrzycy przedciążowej z powikłaniami naczyniowymi. Ukończenie ciąży drogą cięcia cesarskiego jest częściej wskazane u ciężarnych z cukrzycą przedciążową niż u tych, u których cukrzyca rozwinęła się w ciąży. Cięcie cesarskie wykonywane jest najczęściej ze wskazań matczynych w podgrupie ciężarnych z cukrzycą przedciążową z powikłaniami naczyniowymi. Słowa kluczowe: ciąża; cięcie cesarskie; cukrzyca; poród przedwczesny. 


\section{INTRODUCTION}

From the obstetric point of view, carbohydrate metabolism disorders coexisting with pregnancy should be divided into two basic categories: pregestational diabetes mellitus (PGDM) and gestational diabetes mellitus (GDM), according to the time relation between conception and the diagnosis as a distinguishing criterion. Under this division, every type of diabetes mellitus recognized before conception, including type 1 , type 2, MODY (Maturity Onset Diabetes of the Young) and others, belongs to PGDM, while gestational diabetes is defined as carbohydrate disorders of different severity that for the first time occurred or were diagnosed in the course of the current pregnancy [1].

As the World Health Organization describes the quest, premature labour is the end of pregnancy taking place between the $23^{\text {rd }}$ and $37^{\text {th }}$ week of gestation, regardless of the birth weight of the neonate. The prevalence of preterm labour differs around the world from 4 to almost $18 \%[2,3]$. In Poland the preterm birth rate reaches $4.5-12 \%$, depending on the region. Despite recent developments in obstetrics, the percentage of premature labour has not decreased significantly. The risk of this complication increases remarkably in the presence of concomitant diabetes, especially in chronic, poorly controlled carbohydrate disorders, accompanied with secondary vascular disease. In this group of women the occurrence of premature labour is as high as 19-45\% $[1,2,3,4,5]$. Preterm birth can be a consequence of both spontaneous uterine contractility and operative birth, preformed with foetal (mainly threatened asphyxia) or maternal indications.

Diabetes mellitus in pregnancy also predisposes patients to perinatal complications, to which many authors include not only particular diseases, but also the need for special procedures like caesarean section, vacuum extraction or forceps traction. From the other point of view, the coexistence of diabetes and pregnancy is not a reason for operative birth, except for those with advanced PGDM resulting in vascular disease, i.e. proliferative retinopathy. In the last group elective caesarean section is recommended $[4,6,7]$. The most prevalent diabetes-associated reason for caesarean birth is the estimation of excessive foetal weight. Such a circumstance increases the risk of mechanical trauma, especially shoulder dystocia, in the course of vaginal birth [8].

The aim of this study was to analyze the course of pregnancy and birth in a cohort of women suffering from diabetes mellitus, taking into account gestational age at birth, birth mode and, in the case of caesarean section, the nature of indications for surgery.

\section{MATERIALS AND METHODS}

1280 women with pregnancy complicated by diabetes mellitus, who gave birth in the third-degree reference centre (university hospital) during a 10-year period, were included into the study group. The information about their pregnancy and birth course were collected from the medical records. In the analyzed decade recommended diagnostic methods differed from the current ones. For this reason the diagnosis of gestational diabetes in the study group was based on the results of screening (Oral Challenge Test $50 \mathrm{~g}$ ) and/or a diagnostic test (Oral Glucose Tolerance Test 75 g), performed in the second half of pregnancy.

The pregnant women were qualified into groups, depending on the class of diabetes coexisting with pregnancy.

1. Gestational diabetes (GD) group contained 1144 women with gestational diabetes mellitus, additionally divided into two subgroups:

- G1 - 620 women with the G1 class of GDM, who needed a diabetic diet only to stay normoglycaemic,

- G2 - 524 participants with the G2 class of GDM, in need of insulin administration despite their diet treatment.

2. Pregestational diabetes (PGD) group gathered 136 women with preexisting diabetes. It was subsequently divided into two subgroups:

- pregestational diabetes of classes B, C and D (BCD) - 103 participants with prepregnancy diabetes mellitus of class $\mathrm{B}$ $(\mathrm{n}=58)$, class $\mathrm{C}(\mathrm{n}=36)$ and class $\mathrm{D}(\mathrm{n}=9)$, according to White's classification,

- VC (pregestational diabetes of classes R, F and RF) - 33 pregnant women with vascular disease secondary to diabetes mellitus, who belonged to class $R(n=27)$, class $F(n=1)$ and class RF, in whom, besides proliferative retinopathy, diabetic nephropathy was also diagnosed $(n=5)$.

When analyzing the course of pregnancy in the diabetic women, prevalence of premature birth, method of birth, and indications for caesarean section were particularly investigated.

Qualitative variables were analyzed with the use of the $\chi^{2}$ test for multi-way tables and, optionally, the $\chi^{2}$ test with Yates' correction. The level of significance $\mathrm{p} \leq 0.05$ was accepted as statistically significant.

\section{RESULTS}

Two criteria were used in the analysis of gestational age at birth. In the first option the $34^{\text {th }}$ week of gestation was indicated as the time for the foetus to reach maturity. The assumption was that at this gestational age, in the case of threatened preterm labour, corticosteroid administration with the intention of foetal maturation acceleration is usually withdrawn. In the GD group $4.3 \%$ of births occurred before the $34^{\text {th }}$ week of gestation, while in the PGD group the percentage of such preterm births was as high as $10.3 \%$ (Table 1). The difference between the GD and PGD groups was statistically significant ( $p=0.0045)$. The prevalence of premature birth was also analyzed in the subgroups, with statistically significant differences between them. The lowest percentage of births before the completion of the $34^{\text {th }}$ week was observed in the G2 subgroup, and the highest was seen in the VC subgroup.

The second studied parameter was gestational age at birth, with the $37^{\text {th }}$ week of gestation as a cut-off point between 
TABLE 1. Births before and after completion of the $34^{\text {th }}$ week of gestation in women with diabetes mellitus

\begin{tabular}{|c|c|c|c|c|}
\hline Group & \multicolumn{2}{|c|}{ Birth time } & Compared & $p$ \\
\hline subgroup & $\begin{array}{c}<34^{\text {th }} \text { week of } \\
\text { gestation } \\
n(\%)\end{array}$ & $\begin{array}{c}\geq 34^{\text {th }} \text { week of } \\
\text { gestation } \\
n(\%)\end{array}$ & \multirow{7}{*}{ GD/PGD } & \multirow{7}{*}{$0.0045^{*}$} \\
\hline $\mathrm{GD}(\mathrm{n}=1139)$ & $49(4.3)$ & 1090 (95.7) & & \\
\hline $\mathrm{G} 1(\mathrm{n}=617)$ & $29(4.7)$ & 588 (95.3) & & \\
\hline $\mathrm{G} 2(\mathrm{n}=522)$ & $20(3.8)$ & 502 (96.2) & & \\
\hline PGD $(n=136)$ & $14(10.3)$ & 122 (89.7) & & \\
\hline $\mathrm{BCD}(\mathrm{n}=103)$ & $10(9.7)$ & 93 (90.3) & & \\
\hline$V C(n=33)$ & $4(12.1)$ & 29 (87.9) & & \\
\hline $\mathrm{G} 1 / \mathrm{G} 2 / \mathrm{BCD} / \mathrm{VC}$ & & & & $0.018^{* *}$ \\
\hline
\end{tabular}

GD - gestational diabetes; PGD - pregestational diabetes; VC - vascular complications

${ }^{*} X^{2}$ test with Yates' correction; * Pearson's $X^{2}$ test

TABLE 2. The number and percentage of premature and mature births in women with diabetes mellitus

\begin{tabular}{|c|c|c|c|c|}
\hline Group & \multicolumn{2}{|c|}{ Birth time } & Compared & p \\
\hline subgroup & $\begin{array}{c}<37^{\text {th }} \text { week } \\
\text { of gestation } \\
n(\%)\end{array}$ & $\begin{array}{c}\geq 37^{\text {th }} \text { week } \\
\text { of gestation } \\
n(\%)\end{array}$ & \multirow{7}{*}{$\mathrm{GD} / \mathrm{PGD}$} & \multirow{7}{*}{$0.002^{*}$} \\
\hline $\mathrm{GD}(\mathrm{n}=1139)$ & 198 (17.4) & 941 (82.6) & & \\
\hline $\mathrm{G} 1(\mathrm{n}=617)$ & $117(19.0)$ & $500(81.0)$ & & \\
\hline $\mathrm{G} 2(\mathrm{n}=522)$ & $81(15.5)$ & 441 (84.5) & & \\
\hline PGD $(n=136)$ & $39(28.7)$ & $97(71.3)$ & & \\
\hline $\mathrm{BCD}(\mathrm{n}=103)$ & $27(26.2)$ & $76(73.8)$ & & \\
\hline$V C(n=33)$ & $12(36.4)$ & $21(63.6)$ & & \\
\hline $\mathrm{G} 1 / \mathrm{G} 2 / \mathrm{BCD} / \mathrm{VC}$ & & & & $0.0027^{* *}$ \\
\hline
\end{tabular}

GD - gestational diabetes; PGD - pregestational diabetes; VC - vascular complications

* $X^{2}$ test with Yates' correction; * Pearson's $X^{2}$ test

preterm and mature labour. As shown in Table 2, as many as $18.8 \%$ of participants gave birth prematurely. The occurrence of preterm birth in the GD group was significantly lower than in the PGD group $(p=0.002)$. Significant differences in the prevalence of premature birth were also found between the analyzed subgroups. As Table 2 illustrates, preterm birth was rarest in subgroup G2 and most frequent in the VC subgroup.

The analysis of the records in the studied population of women with diabetes mellitus led to a similar percentage of caesarean sections and vaginal births (51.4 vs. $48.6 \%$ ). $5.9 \%$ of participants had their birth induced with pharmacological agents administration or by amniocentesis, and uterine activity augmentation by oxytocin administration in the course of vaginal birth was performed in $12.4 \%$ of women. Table 3 shows that the way of birth was closely associated with the type of diabetes mellitus, since the proportion of caesarean section was significantly lower in the GD group in comparison to the PGD group (47.9 vs. 74.3; $\mathrm{p}<0.001$ ). Also, the differences in the way of birth observed between subgroups were significant. In the VC subgroup the percentage of caesarean births was
TABLE 3. The prevalence of vaginal and caesarean births among women with diabetes mellitus

\begin{tabular}{|c|c|c|c|c|}
\hline Group & Birth & lode & $\begin{array}{c}\text { Compared } \\
\text { groups }\end{array}$ & $\mathrm{p}$ \\
\hline subgroup & $\begin{array}{l}\text { vaginal } \\
\text { n (\%) }\end{array}$ & $\begin{array}{c}\text { caesarean } \\
\text { n (\%) }\end{array}$ & \multirow{7}{*}{ GD/PGD } & \multirow{7}{*}{$0.000001^{*}$} \\
\hline $\mathrm{GD}(\mathrm{n}=1143)$ & $595(52.06)$ & $584(47.94)$ & & \\
\hline $\mathrm{G} 1(\mathrm{n}=620)$ & $332(53.55)$ & $288(46.45)$ & & \\
\hline $\mathrm{G} 2(\mathrm{n}=523)$ & $263(50.29)$ & $260(49.71)$ & & \\
\hline $\operatorname{PGD}(n=136)$ & $35(25.74)$ & $101(74.26)$ & & \\
\hline$B C D(n=103)$ & $34(33.01)$ & 69 (66.99) & & \\
\hline$V C(n=33)$ & $1(3.03)$ & $32(96.97)$ & & \\
\hline $\mathrm{G} 1 / \mathrm{G} 2 / \mathrm{BCD} / \mathrm{VC}$ & & & & $0.000001^{* *}$ \\
\hline
\end{tabular}

TABLE 4. Maternal and foetal indications for caesarean section among women with diabetes mellitus

\begin{tabular}{|c|c|c|c|c|}
\hline Group & $\begin{array}{r}\text { Indications } \\
\text { b }\end{array}$ & $\begin{array}{l}\text { r caesarean } \\
\text { h }\end{array}$ & $\begin{array}{l}\text { Compared } \\
\text { groups }\end{array}$ & $\mathrm{p}$ \\
\hline subgroup & $\begin{array}{c}\text { maternal } \\
\mathrm{n}(\%)\end{array}$ & $\begin{array}{l}\text { foetal } \\
\text { n (\%) }\end{array}$ & \multirow{7}{*}{ GD/PGD } & \multirow{7}{*}{$\mathrm{NS}^{*}$} \\
\hline $\mathrm{GD}(\mathrm{n}=348)$ & $229(43.37)$ & $299(56.63)$ & & \\
\hline $\mathrm{G} 1(\mathrm{n}=277)$ & $115(41.52)$ & $162(58.48)$ & & \\
\hline $\mathrm{G} 2(\mathrm{n}=251)$ & $114(45.42)$ & $137(54.58)$ & & \\
\hline PGD (n = 95) & $46(48.42)$ & $49(51.58)$ & & \\
\hline $\mathrm{BCD}(\mathrm{n}=67)$ & $26(38.81)$ & $41(61.19)$ & & \\
\hline$V C(n=28)$ & $20(71.43)$ & $8(28.57)$ & & \\
\hline $\mathrm{G} 1 / \mathrm{G} 2 / \mathrm{BCD} / \mathrm{VC}$ & & & & $0.02^{* *}$ \\
\hline
\end{tabular}

GD - gestational diabetes; PGD - pregestational diabetes; VC - vascular complications

${ }^{*} X^{2}$ test with Yates' correction; * Pearson's $X^{2}$ test

close to 100, while the lowest occurrence of operative births was noticed in subgroup G1.

Detailed indications for the surgery of 649 women with diabetes mellitus who delivered by caesarean section were analyzed according to their medical record. The indications were categorized as maternal - due to the state of the pregnant or parturient woman, and foetal, implicated by known or expected foetal disorders. If more than one indication was noticed, only the absolute one was taken into account. It was found that $55.8 \%$ of caesarean births among women with diabetes mellitus were performed because of a foetal condition. The other $44.2 \%$ of indications were of a maternal nature. These results are shown in Table 4. In the GD group, as well as in the PGD group, caesarean birth was performed slightly more often because of foetal rather than maternal indications. However, the difference observed was not significant. The comparison of particular subgroups yielded statistically significant differences, as seen in Table 4. Foetal indications for caesarean section slightly prevailed in subgroups G1, G2 and BCD, whilst in the VC subgroup most indications were of maternal conditions. 


\section{DISCUSSION}

Pregnancy accompanying diabetes is a well-known risk factor of preterm birth. What should be emphasized is that the severity of risk depends on additional factors characterizing carbohydrate intolerance in detail, like its type, duration, metabolic control adequacy, secondary vascular disease, etc. Diabetes in pregnancy also increases the probability of caesarean birth, for foetal as well as for maternal indications, often related to pathological conditions secondary to metabolic abnormalities. Our study group was analyzed from two points of view in regard to premature birth. The first took into account practical reasons, with foetal maturity meant as the stage of pregnancy making glucocorticosteroids administration unnecessary. The second considered the classic definition of preterm birth as that completed before the $37^{\text {th }}$ week of gestation.

We found that the prevalence of birth before completion of the $34^{\text {th }}$ week of gestation was over twice as high in women suffering from PGDM as in those with GDM, and the difference was statistically significant. It was also significant, although not so outstanding, between groups of participants who gave birth before and after the $37^{\text {th }}$ week of gestation.

Shefali et al., despite having received a much smaller difference between risk of premature birth in PGDM in comparison with GDM, still confirmed its dependence on the type of diabetes [9].

Sendag et al. found no difference in preterm birth prevalence between non-diabetic women and those with G1 diabetes mellitus, but such a difference was significantly higher in participants who required insulin administration in comparison with those who achieved euglycemia only with diet treatment [10]. This is not consistent with our experience, because in the GDM study group we found only small differences between G1 and G2 patients, and, what is noticeable, the incidence of premature birth was paradoxically slightly higher in women receiving only diet treatment. This may result from inadequate diabetic care, having overlooked the moment to change the patient's qualification to G2 group, or from the negligent approach of patients themselves, believing that a complication not requiring pharmacologic treatment cannot have an impact on their health.

The French Diabetes and Pregnancy Group describes the rate of premature birth among pre-pregnancy diabetes women as $38.2 \%$, which is clearly higher than the $28.7 \%$ found in our study, but there is no dissonance in the conclusion that secondary complications, like nephropathy, increase the risk of preterm birth, which was also obvious in our study considering the $34^{\text {th }}$ and $37^{\text {th }}$ week of gestation as foetal maturity [11].

Analyzing women with type 1 pre-pregnancy diabetes, Eidem et al. got the result of $26.4 \%$ of preterm births, which is very similar to our $26.3 \%$ in participants with type 1 and type 2 PGDM. The authors also investigated the prevalence of very premature birth, meant as completed before the $32^{\text {nd }}$ week of gestation, yielding 3.4\% [12]. A comparison of this result with our $10.3 \%$ of births before the $34^{\text {th }}$ week of gestation would not be reasonable for significant differences in foetal maturation in these stages of pregnancy, and, what follows, in neonatal prognosis. The ratio of this percentage, with only 2 weeks of pregnancy between them, can, however, be an illustration of the increasing occurrence of preterm birth in the course of diabetic pregnancy.

Gillespie et al. found a general tendency in GDM women to deliver earlier than non-diabetic women, and accentuated cost generation due to higher rates of emergency caesarean sections in this group [13]. The last could be the consequence of not only evident maternal and/or foetal condition, but also a medical professional's overreaction, who might more easily convert from vaginal to caesarean birth in the case of a patient with pre-labour complications.

Gui et al. compared groups of pregnant women with prepregnancy diabetes, and mild and severe gestational diabetes, which we consider as analogous to PGDM, G1 and G2, and noticed $36.5 \%$ of preterm births in the PGDM group, which is higher than the $28.7 \%$ found in our study [14]. The authors' results show higher occurrence of preterm birth in PGDM than in mild and severe GDM, which is consistent with our evidence, although in our study the incidence of this complication was slightly higher in the G1 than in the G2 group. Gui et al. also found statistically significant difference in general pregnancy duration, with the longest in the group of mild GDM and the shortest in women with severe GDM [14].

Khan et al. described the prevalence of preterm birth in Pakistani women with GDM to be as high as $25.2 \%$, which, in comparison with our $17.3 \%$, would confirm geographic and ethnic factors as important for the natural history of both gestational diabetes and premature labour [15].

Comparing non-diabetic women with those suffering from GDM, Gasim found a statistically significant difference in pregnancy duration, but denied higher incidence of preterm birth in the diabetic group, which is interesting because even pregnancy-induced carbohydrate intolerance is believed to increase the risk of premature birth [16]. It is also in contrast to our result, $17.3 \%$ of premature births in the GDM group, which clearly differs from the Polish average of $6 \%$, strongly suggesting gestational diabetes to be an important risk factor of preterm birth [17]. Similarly to Gasim, Mitrović et al., in 5-year follow-up, found patients with diabetes in pregnancy as tending to give birth 1 or 2 weeks earlier than non-diabetic women. Like the previous authors, they did not find a statistically significant difference in the occurrence of preterm birth between diabetic and healthy participants. They also negated such a difference comparing type 1 diabetic women with those suffering from type 2 or gestational diabetes, while in our study participants with pre-pregnancy diabetes differed significantly from women with GDM [18]. The inconsistence with our findings can have its source in the different qualification of premature birth, as Mitrović et al. took into account the $36^{\text {th }}$, and not the $37^{\text {th }}$ week of gestation as complete foetal maturity. The second possible reason is the alternative composition of study groups, because Mitrović et al. compared women with type 1 diabetes mellitus with patients with gestational diabetes and type 2 pre-gestational diabetes taken together, while in our study the comparison was between pre-pregnancy diabetic 
women and those with gestational diabetes. But it is still worth remembering that the risk of preterm birth depends not only on the presence or absence of diabetes and its type, but also on the access, mode and quality of medical care, the adequacy of metabolic control, and the occurrence of additional complications of pregnancy [18, 19, 20, 21, 22, 23].

Kaymak et al. analyzed women with single abnormal results of GCT, OGTT and diagnosed with pre-pregnancy and gestational diabetes, comparing them with those with uncomplicated pregnancy. They found a statistically significant difference in pregnancy duration, with the shortest in the diabetic group, and in the prevalence of preterm birth, which was also the highest in women with GDM and PGDM, and the lowest in those with uncomplicated pregnancy [19]. It is not possible to compare it directly to our findings because of a lacking non-diabetic control group in our study, but it is closer to our results than the absence of additional risk of preterm birth in diabetic pregnancy, as in the previous authors' conclusion.

In their retrospective study, Köck et al. compared diabetic women with healthy pregnant women, finding a significant difference of preterm birth occurrence with, in detail, a higher prevalence of spontaneous preterm birth in diabetic patients. Such a result helps to exclude iatrogenic procedures as a factor increasing the percentage of premature birth in diabetic patients [20].

Temple et al. analyzed the influence of pre-pregnancy care on obstetric outcomes in women with type 1 diabetes mellitus. They proved the reducing effect of pre-pregnancy care on the probability of premature birth before the $34^{\text {th }}$ but not before the $37^{\text {th }}$ week of gestation [21].

Potti et al. emphasized the importance of coexisting pregnancy complications for the occurrence of preterm birth, showing its percentage in studied diabetic women as 12.9, while reaching 30.8 in those who suffered additionally from hypertensive disorders [22]. In our study we did not analyze such an impact, but, comparing pre-pregnancy diabetic participants with and without secondary vascular diseases, having, respectively 26.2 and $36.4 \%$ of preterm births, we also found the risk of preterm birth in diabetic patients to be associated with the presence of extra complications.

Searching for the risk factors of premature labour in type 1 diabetic woman, Lepercq et al. referred to $22-45 \%$ of preterm births in this group as described in the literature, posing the question of whether the cause could be iatrogenic. They found overall preterm birth incidence to be $24 \%$, with only $9 \%$ of them completed as a spontaneous process and $15 \%$ as indicated for extra complications like progression of nephropathy, chronic hypertension or preeclampsia [23]. This is generally consistent with our conclusion of increased risk in women with diseases secondary to the diabetes. However, we did not analyze in detail the influence of particular complications, taking into account type 1 diabetic women with and without vascular complications of pre-pregnancy diabetes.

Spiegler et al. investigated the influence of diabetes on the risk of very premature birth, surprisingly finding no significant connection between these two conditions [24]. The limitation of above study is the identification of neonates with very low birth weight born in the $22^{\text {nd }}-36^{\text {th }}$ week of gestation with those delivered prematurely, not taking into account premature newborns presenting birth weight adequate for gestational age.

As Canadian opponents of the International Association of the Diabetes and Pregnancy Study Groups' (IADPSG) regulations, Bodmer-Roy et al., compared women who fulfilled IADPSG but not Canadian Diabetes Association (CDA) criteria for GDM diagnosis with healthy women according to both tests results [25]. They found no statistically significant difference between the investigated groups in preterm labour incidence, concluding that too wide a criteria of GDM identification leads to unnecessary diagnoses in women who are not at risk of pregnancy complications. It is not possible to strictly relate our results to the findings above because of our having used diagnostic criteria also different from those of the CDA as from today's IADPSG regulations. Our study showed that even carbohydrate intolerance of such low severity as class 1 gestational diabetes increases the risk of preterm end of pregnancy. Nevertheless, the search for accurate diagnostic criteria should not be neglected.

Another question posed in our study was the association between type and class of diabetes in pregnancy and the prevalence of caesarean section. What should be noted is that Polish recommendations indicate caesarean birth in all diabetic women with secondary vascular disease, which makes vaginal birth in this group quite rare.

We found a statistically significant difference in the incidence of caesarean section between women with gestational and pre-gestational diabetes mellitus, with the highest rate of surgery in the second group. This significance was also present in a comparison of subgroups according to class of diabetes. Generally, the rate of caesarean section increased with the severity of the complication. The highest percentage of caesarean birth was, of course, in the VC subgroup, which is consistent with the Polish Gynaecological Society's recommendations, as mentioned above. The lowest was in the G1 subgroup, characterized with mild carbohydrate intolerance, requiring diet treatment only.

Shefali et al. compared the rate of assisted birth, meaning not only caesarean section, but also vacuum extractor or forceps assisted vaginal birth, in pre-gestational and gestational diabetic women with non-diabetic women. They found a very similar percentage of these procedures in both diabetic groups, respectively 60.8 and 59.6 , in contrast to $20 \%$ in the non-diabetic group, which confirmed the predisposition to assisted birth following carbohydrate disorders in pregnancy [9]. We cannot strictly refer to these results because of the lack of a control group of healthy women in our study, but the similarity of assisted birth between both PGDM and GDM groups are in contrast to our findings, with much higher results in the pre-gestational diabetes group. Such inconsistence may come from the different medical care models used in Poland and India. Another probable cause is the mode of criteria construction. In our research we excluded vacuum extractor and forceps assisted births from the study, focusing only on caesarean section. 
Sendag et al. found a significantly higher rate of caesarean birth in women with gestational diabetes in comparison with non-diabetic women, proving the dependence of operative birth occurrence on maternal metabolic status. The percentage of caesarean birth (41.4) was slightly lower but still proportional to our result (47.9). They also compared the prevalence of operative birth between GDM patients, finding it at a level of $38 \%$ in the G1 group and 60\% in the G2 group, which, surprisingly, did not generate a significant difference [10].

Gillespie et al. reached a similar conclusion when comparing the occurrence of caesarean birth in non-diabetic women with those with GDM. They found a statistically significant difference between the analyzed groups, and emphasized the cost increase caused by the high prevalence of gestational diabetes and its consequences [13]. What is interesting, however, is that the rate of elective and emergency caesarean section was significantly higher in the GDM group (12.4 and 13.6, respectively), but it was still much lower than our results.

Khan et al. also noticed a significantly higher prevalence of caesarean and instrumental births in women with GDM (35\%) in comparison with non-diabetic women (24.7\%), which is still over $12 \%$ lower than our result [15].

Similarly, Gasim, analyzing 220 women with GDM, found a statistically significant higher percentage of caesarean section in this group, compared with non-diabetic controls [16]. As in the studies cited above, his result was much lower (24.1\%) than the analogous result found in our research.

The French Diabetes and Pregnancy Group describes the caesarean birth rate in pre-gestational diabetic women as 58.9\%, which is definitely lower than the $74.3 \%$, found in our study [11].

In their research Temple et al. investigated the influence of the presence or absence of pre-pregnancy care on the prevalence of caesarean birth in type 1 diabetic women, not finding a statistically significant difference in this aspect [21]. Independently from pre-conceptional care in diabetic patients, caesarean birth occurrence exceeded $65 \%$, which, however, is still noticeably lower than found in the PGDM group in our study.

Gui et al. did not find significant differences when analyzing the percentage of caesarean births in pre-pregnancy diabetic women compared with those with mild and severe gestational diabetes [14]. What is intriguing is that the rate of caesarean birth in all groups was very high, with the highest, 92.9, in mild gestational diabetic women, which differs from our findings, with as low as 46.4 prevalence of surgical procedure.

Mitrović et al. found $78.26 \%$ of caesarean births in type 1 diabetic women, with a significant difference in comparison to the second group composed of participants with GDM and type 2 diabetes, in which the rate was only $41.3 \%$ [18]. These results can be interpreted as similar to ours. However, in our study participants with type 1 and type 2 diabetes were qualified to the same group, and those with GDM to another.

Kaymak et al. yielded $49 \%$ of primary caesarean sections in women with pre-pregnancy and gestational diabetes, with a significant difference compared to non-diabetic participants and those who were verified as non-diabetic in the course of diagnosis [19]. In our study a similar result was found only in the GDM group, while in PGDM the rate of caesarean births was as high as $74.3 \%$.

Consistently, Köck et al. found a significantly higher rate of operative birth in the PGDM-GDM group when compared with the healthy control [20]. They noticed $31.4 \%$ of elective and $14 \%$ of intrapartum caesarean sections in diabetic women, still reaching a lower surgical birth percentage than that calculated in our study.

Potti et al. proved that the risk of elective and intrapartum caesarean section in diabetic women depends not only on carbohydrate intolerance characteristics, but is also increased in the presence of extra complications, i.e. hypertensive disorders [22].

Bodmer-Roy et al. did not find a significant difference in the intrapartum caesarean birth rate between healthy women and those with GDM diagnosed according to IADPSG but not CDA recommendations. However, when analyzing all categories of caesarean sections together, they found a significantly higher rate in the GDM group [25].

\section{CONCLUSIONS}

1. Diabetes mellitus accompanying pregnancy increases the risk of preterm birth.

2. Premature labour is more prevalent in women with prepregnancy diabetes mellitus, especially complicated by secondary vascular disease, than in those with gestational diabetes.

3. Caesarean birth is more often necessary in women with coexisting pre-pregnancy diabetes than in those with gestational diabetes mellitus.

4. The most typical caesarean section among the diabetic women is that performed because of maternal indications in patients with pre-pregnancy diabetes mellitus complicated by secondary vascular disease.

\section{REFERENCES}

1. American Diabetes Association: Clinical practice recommendations 1999. Diabetes Care 1999;22 Suppl. 1:S1-S114.

2. Lawn JE, Gravett MG, Nunes TM, Rubens C, Stanton C. Global report on preterm birth and stillbirth ( 1 of 7): definitions, description of the burden and opportunities to improve data. BMC Pregnancy Childbirth 2010;10 Suppl 1:S1. doi: 10.1186/1471-2393-10-S1-S1.

3. Blencowe H, Cousens S, Oestergaard MZ, Chou D, Moller AB, Narwal R, et al. National, regional, and worldwide estimates of preterm birth rates in the year 2010 with time trends since 1990 for selected countries: a systematic analysis and implications. Lancet 2012;379(9832):2162-72. doi: 10.1016/S0140-6736(12)60820-4.

4. Cypryk K, Wilczyński J, Bliźniewska K. Cukrzyca a ciąża - problem interdyscyplinarny. Diabetol Pol 1998;5 Suppl 1:64-8.

5. Pedersen J, Pedrsen LM. Prognosis of the outcome of pregnancies in diabetics. Acta Endocrinol (Copenh) 1965;50(1):70-8.

6. Adams KM, Li H, Nelson RL, Ogburn PL Jr, Danielko-Dixon DR. Sequel of unrecognized gestational diabetes. Am J Obstet Gynecol 1998;178(6):132132.

7. Standards of the Polish Gynecological Society of proceeding with women with diabetes. Ginekol Dypl 2006;8:67-74. 
8. Moyer VA. Screening for gestational diabetes mellitus: U.S. Preventive Services Task Force recommendation statement. Ann Intern Med 2014;160(6):414-20. doi: 10.7326/M13-2905.

9. Shefali AK, Kavitha M, Deepa R, Mohan V. Pregnancy outcomes in pregestational and gestational diabetic women in comparison to non-diabetic women - a prospective study in Asian Indian mothers (CURES-35). J Assoc Physicians India 2006;54:613-18.

10. Sendag F, Terek MC, Itil IM, Oztekin K, Bilgin O. Maternal and perinatal outcomes in women with gestational diabetes mellitus as compared to nondiabetic controls. J Reprod Med 2001;46(12):1057-62.

11. Boulot P, Chabbert-Buffet N, d'Ercole C, Floriot M, Fontaine P, Fournier A, et al. French multicentric survey of outcome of pregnancy in women with pregestational diabetes. Diabetes Care 2003;26(11):2990-3.

12. Eidem I, Vangen S, Hanssen KF, Vollset SE, Henriksen T, Joner G, et al. Perinatal and infant mortality in term and preterm births among women with type 1 diabetes. Diabetologia 2011;54(11):2771-8. doi: 10.1007/ s00125-011-2281-7.

13. Gillespie P, Cullinan J, O'Neill C, Dunne F. Modeling the independent effects of gestational diabetes mellitus on maternity care and costs. Diabetes Care 2013;36(5):1111-6. doi: 10.2337/dc12-0461.

14. Gui J, Li A, Su X, Feng L. Association between hyperglycemia in middle and late pregnancy and maternal-fetal outcomes: a retrospective study. BMC Pregnancy Childbirth 2014;14:34. doi: 10.1186/1471-2393-14-34.

15. Khan R, Khurshid A, Khan Z. Maternal and fetal outcome of gestational diabetes mellitus. Gomal J Med Sci 2013;11(1):88-91.

16. Gasim T. Gestational diabetes mellitus: maternal and perinatal outcomes in 220 Saudi women. Oman Med J 2012;27(2):140-4. doi: 10.5001/omj.2012.29.

17. Demografic Yearbook of Poland. Warsaw: Statistical Publishing Establishment; 2014.
18. Mitrović M, Stojić S, Tešić DS, Popović D, Rankov O, Tomić-Naglić D, et al. The impact of diabetes mellitus on the course and outcome of pregnancy during a 5-year follow-up. Vojnosanit Pregl 2014;71(10):907-14.

19. Kaymak O, Iskender CT, Ustunyurt E, Yildiz Y, Doganay M, Danisman N. Retrospective evaluation of perinatal outcome in women with mild gestational hyperglycemia. J Obstet Gynaecol Res 2011;37(8):986-91. doi: 10.1111/j.1447-0756.2010.01469.x.

20. Köck K, Köck F, Klein K, Bancher-Todesca D, Helmer H. Diabetes mellitus and the risk of preterm birth with the regard to the risk of spontaneous preterm birth. J Matern Fetal Neonatal Med 2010;23(9):1004-8. doi: 10.3109/14767050903551392.

21. Temple R, Aldridge V, Murphy HR. Prepregnancy care and pregnancy outcomes in women with type 1 diabetes. Diabetes Care 2006;29(8):1744-9. doi: 10.2337/dc05-2265.

22. Potti S, Jain NJ, Mastrogiannis DS, Dandolu V. Obstetric outcomes in pregnant women with diabetes versus hypertensive disorders versus both. J Matern Fetal Neonatal Med 2012;25(4):385-8. doi: 10.3109/14767058.2011.580403.

23. Lepercq J, Coste J, Theau A, Dubois-Laforgue D, Timist J. Factors associated with preterm birth in women with type 1 diabetes. A cohort study. Diabetes Care 2004;27(12):2824-8.

24. Spiegler J, Stichtenoch G, Weichert J, König IR, Schlaud M, Wense A, et al. Pregnancy risk factors for very premature birth: what role do hypertension, obesity and diabetes play? Arch Gynecol Obstet 2013;288(1):57-64. doi: 10.1007/s00404-013-2739-6.

25. Bodmer-Roy S, Morin L, Cousineau J, Rey E. Pregnancy outcomes in women with and without gestational diabetes mellitus according to The International Association of the Diabetes and Pregnancy Study Groups criteria. Obstet Gynecol 2012;120(4):746-52. doi: 10.1097/AOG.0b013e31826994ec. 